\title{
Biotech Blue
}

\section{Agouron annexes Alanex}

As rational drug designers and combinatorial chemists continue to compete for position in the pharmaceutical drug-discovery arena, Agouron Pharmaceuticals (La Jolla, CA) has joined the fray by acquiring the computational combinatorial chemistry company Alanex Corporation (San Diego, CA) at the end of April for $\$ 62$ million in newly issued Agouron stock. Targeting the molecular structure of proteins that play key roles in disease, Agouron uses a 3D-structure computational technology to design such small-molecule drugs as the recently FDA-approved HIV protease inhibitor, Viracept. Alanex's software extends the Agouron technology by creating large combinatorial libraries from an Agouron proteinstructure target, and then examining each member of the library in a linked high-throughput screening system. "We were very impressed by the competitive position of Alanex in the area of targeted combinatorial chemistry, and impressed with the contributions that Alanex's proprietary research projects could make to our development pipeline," says Peter Johnson, Agouron president and CEO. Agouron is particularly interested in the Alanex in-house effort to identify drugs that act as antagonists to gonadotropin-releasing hormone--drugs that may be a potential treatment for endometriosis and some types of cancer. "Access to Agouron's development and marketing capabilities will also assure the progress of Alanex's proprietary development projects," says Marvin Brown, president and CEO of Alanex.

\section{IMAGE \\ UNAVAILABLE FOR COPYRIGHT REASONS}

The hoopla generated by the chess rematch between IBM's (Armonk, NY) Deep Blue supercomputer and grandmaster Garri Kasparov has underscored yet again our fascination with pitting ourselves against machines. This particular machine,

however, may prove to be a potent

ally of biomedical researchers.

Although known by the less catchy

"RS/6000 SP," IBM's commercial versions of Deep Blue work at a

mind-boggling pace, performing

hundreds of millions of calcula-

tions per second and sifting

through massive amounts of data.

"Technical industries needing

heavy simulation, like biotech, are

the bleeding edge," says Eric

Rosencrans, IBM manager of SP

market development, comment-

ing that IBM sees biotechnology as one of

the most demanding proving grounds for

SP technology. The pharmaceutical indus-

try is keen to employ RS/6000 SP in molec-

ular dynamics simulations - which involve

enormous numbers of calculations to pre-

\section{FDA and Pharmanex clash over dietary supplement}

What do you do when you think your product is a dietary supplement, but the US Food and Drug Administration (FDA; Rockville, MD) says it is an unapproved drug and therefore illegal? If you are Pharmanex-a Simi Valley, California-based startup founded last year-you seek judicial clarification in Utah state district court. Pharmanex's cholesterol-reducing product Cholestin-a product based on an ancient Chinese remedy in which rice is fermented by the red yeast Monascus purpureushas been sold over the counter as a supplement since November last year. In February 1997 , the company launched a glitzy $\$ 20$ million advertising campaign touting the benefits of Cholestin. Company alarm bells started ringing, however, when the FDA turned up at Pharmanex headquarters in March requesting documentation on the

Business \& Regulatory News Briefs written by Emma Dorey, John Hodgson, Josh Lehrer (a science writer based in Los Angeles, CA), Andrew Marshall, and Debra Robertson (a freelance writer working in San Diego, CA). dict the interactions between atoms and molecules-in the design of drug therapies. A typical drug takes 12 years to reach the market. IBM estimates that Deep Blue could cut development time to $4-6$ years,

\section{IMAGE \\ UNAVAILABLE FOR COPYRIGHT REASONS}




\section{Gene of the month}

Scientists at the US National Institutes of Health (NIH; Bethesda, MD) have reported the cloning of a gene involved in endocrine cancers (Science, 276:404-407, April 18). The gene is linked to multiple endocrine neoplasiatype I (MENI), a hereditary cancer syndrome esti-

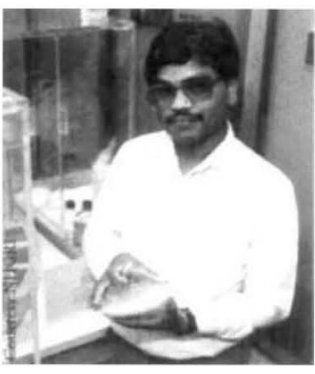
mated to occur in between 1 in 10,000 and 1 in 100,000 people worldwide, causing tumors of the parathyroids, enteropancreatic tissues, and anterior pituitary gland. Most MEN1 tumors are nonmetastisizing, but can cause severe effects because of their secretion of such endocrine substances as insulin and growth hormone. During the search for $M E N 1$, which began nine years ago when a segment of chramosome 11 was linked to endocrine cancers, the $\mathrm{NIH}$ researchers sorted through over 30 candidate genes before finding the culprit; the MEN1 mutations-found in 14 of the 15 unrelated cancer patients studied-would probably result in disfunction of the protein product, menin, suggesting that $M E N 1$ is a tumor-suppressor gene.

Interestingly, sequence analysis shows that menin bears little resemblance to any known protein. "The sequence has been searched exhaustively and nothing has come up. It's still unclear what role [menin] plays in normal cell biology," says the study's lead author Settara Chandrasekharappa. Because the predicted menin sequence is so unusual, researchers believe that further studies on $M E N 1$ may expose new oncogenesis mechanisms. In addition, $M E N 1$ is expressed throughout the body, suggesting that it may be involved in other types of cancer.

\section{Cortech downsizes}

Cortech (Denver, CO) on April 24 announced the decision to slash its full-time staff by $60 \%$ in response to the phase II trial failure of its lead drug, Bradycor; partial data from the suspended trial failed to demonstrate that Bradycor significantly affects its primary target, intracranial pressure. The bad news for Bradycor-a bradykinin antagonist intended to treat brain trauma-began last year when unexplained mortality was shown in animal studies; Cortech's partner, SmithKline Beecham, subsequently suspended the human trials. Since Bradycor's failure,
Cortech shares have plummeted, losing over $60 \%$ of their value. According to Cortech chief financial officer Joseph Turner, "In the wake of the downsizing, the company continues to carefully review its strategic options with the objectives of conserving cash while retaining significant value-creative potential." These options include the possible sale of the company, says Turner. Cortech's current research centers on developing a protease neutrophil elastase inhibitor-a potential therapy for respiratory and arthritic disorders-in partnership with Ono Pharmaceuticals (Osaka, Japan). As part of a recent revision in the partnership contract, Ono will now assume all research responsibilities for the six-month remainder of their current partnership agreement.

\section{6 companies, 1 cloned sheep}

In European Biotech 97; A New Economy, international accountant Ernst \& Young reports that Europe now has 716 biotechnology companies up from 584 the previous year, and one cloned sheep (Dolly is mentioned repeatedly throughout the report). The UK leads the way with over 180 companies (and the cloned sheep), but France and Germany both have over 100 biotechnology companies, and Sweden and the Netherlands over 50 each. The headline numbers would suggest that Europe is catching up nicely to the United States and its companies.

But are the companies comparable? The average R\&D spending per European company, for instance, was around $40 \%$ of that of US companies [Ecu 2 million ( $\$ 2.3$ million) versus Ecu 4.91 million ( $\$ 5.64$ million)]; the average revenue only $30 \%$; and the average number of employees $45 \%$. The implication is that European biotechnology companies individually and collectively are just a smaller version of their US counterparts.

But, in reality, corporate European biotechnology is not like that. Nearly a quarter of US biotechnology companies are publically quoted; fewer than $7 \%$ of the Europeans are. Many of the "biotechnology" companies in Europe have not been built on venture capital but on sales or loans. Proportionally more companies in Europe are involved in agriculture, environmental or industrial activity. E\&Y's number crunching disguises these differences.

\begin{tabular}{|c|c|}
\hline \multicolumn{2}{|c|}{ FDA commissioner candidates: Short list } \\
\hline Name & Affiliation \\
\hline Gilbert Omenn & $\begin{array}{l}\text { University of Washington } \\
\text { School of Public Health and } \\
\text { Community Medicine Dean }\end{array}$ \\
\hline Randy Juhi & $\begin{array}{l}\text { University of Pittsburgh } \\
\text { Pharmacy School Dean }\end{array}$ \\
\hline Steven Phillips & lowa cardiac surgeon \\
\hline Ann Brown & $\begin{array}{l}\text { Consumer Products } \\
\text { Safety Commission Chair }\end{array}$ \\
\hline Michael Taylor & $\begin{array}{l}\text { Former FDA Deputy } \\
\text { Commissioner }\end{array}$ \\
\hline Myron Weisfeldt & $\begin{array}{l}\text { Columbia University Dept. } \\
\text { of Medicine Chair }\end{array}$ \\
\hline Janet Woodcock & $\begin{array}{l}\text { Center for Drug Evaluation } \\
\text { and Research Director }\end{array}$ \\
\hline
\end{tabular}

\section{Suppressed Synthroid study released}

After years of acrimonious wrangling, Knoll Pharmaceuticals (Mount Olive, NJ) finally bowed to pressure and allowed publication of a study by University of California, San Francisco researchers (JAMA 277:1205-1213, 1997). The study showed that their blockbuster drug, Synthroid, was no more effective than generic versions.

Synthoid saga: A decade-long dispute.

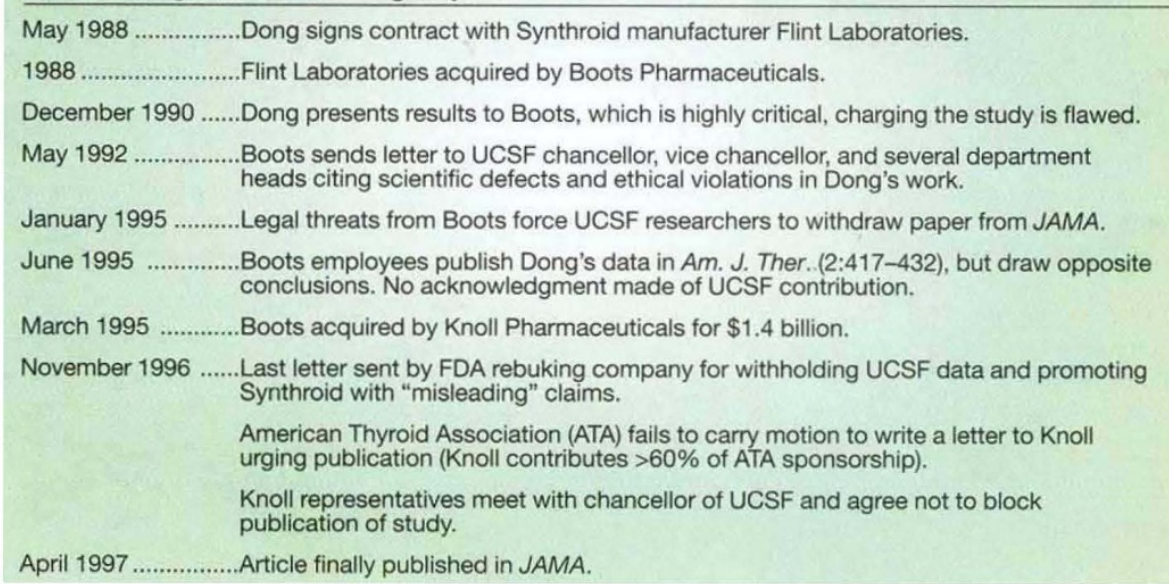




\section{Epitope dumps A\&W over bad berries}

The US Department of Agriculture (USDA; Washington, DC) in April announced the suspension of Andrew and Williamson Sales Co. (A\&W; San Diego, CA) - a subsidiary of Epitope (Beaverton, OR)-from the agency's schoollunch program for misrepresenting the

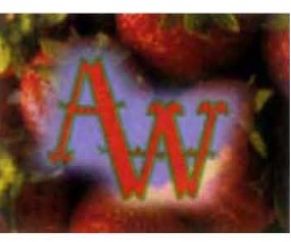
origin of allegedly tainted strawberries linked to a hepatitis A outbreak in Michigan earlier that month. While claiming to have been "grown and packed in the United States," the berries were actually grown in Mexico and packed in San Diego. A\&W used the misleading labels prior to Epitope's acquisition of A\&W in December 1996. According to Epitope spokesperson Mary Hagen, A\&W was originally acquired because Epitope "felt it was a good means to utilize Epitope's genetic engineering technology for fruits and vegetables." In response to the crisis, which sent Epitope shares tumbling 19\%, Epitope asked A\&W president Fred Williamson to resign,

\section{WTO KOs Euro beef ban}

In a far-reaching decision, the World Trade Organization (WTO; Geneva) has ruled that the European Union's (EU) ban on hormone-treated beef is illegal. The May 8 decision is the first to uphold a previous WTO agreement that food-product restrictions aimed at protecting human health must be supported by scientific evidence. Farmers from America and other non-European cattle-producing nations routinely use five hormones, including progesterone and testosterone, to accelerate cattle growth and milk production. The EU imposed the ban in 1988, addressing widespread consumer concern over chemical treatments. Accord-

ing to a US Government official, the report clearly states that the EU failed to justify its ban on hormone-treated beef with good science, and that the preliminary ruling suggests that the WTO "can effectively draw upon scientific experts to reach findings in complex technical cases," adding that "the panel has demonstrated that the WTO can work for US interests, including US agricultural and biotechnology interests." The WTO ruling could have direct implications for potential disputes over genetically engineered foodstuffs - an encouraging sign for the biotechnology industry and for companies already marketing genetic crops. A final ruling is expected from the WTO this month, after which either side can appeal the decision.

and Epitope has agreed with the former owners of A\&W to annul its December 1996 acquisition of $A \& W$; the agreement will release Epitope from any liabilities arising from A\&W's handling of the allegedly tainted strawberries. In the aftermath of the strawberry scandal, a number of consumer groups have lobbied President Clinton, calling for the creation of a single federal food-safety agency; currently, numerous agencies oversee food safety, including the USDA, the Food and Drug Administration (Rockville, MD), and the Environmental Protection Agency (Washington, DC).

\section{Joint Ventures}

\begin{tabular}{ll}
\hline Company 1 & Company 2 \\
Schering Plough & Myriad Genetics \\
(Madison, NJ) & (Salt Lake City, UT)
\end{tabular}

FibroGen Europe

(Oulu, Finland)

Rhône-Poulenc Rorer

Australia

Cubist Pharmaceuticals (Cambridge, MA)

Helix Biopharma

(Richmond,

British Columbia,

Canada)

Chiron

(Emeryville, CA)
Technology Development Center (TDC)

(Government of Finland))

AMRAD Discovery

Technologies

(Kew, Victoria, Australia)

Novalon Pharmaceutical (Chapel Hill, NC)

PharmaDerm Laboratories (Saskatoon, Canada)

Biomira

(Edmonton, Alberta,

Canada)

\section{$\$$ Million Details}

A five-year research program combining Myriad's gene-discovery and protein-interaction knowledge with Schering's development and marketing experience to target five genes and develop cancer therapies. Payments to Myriad for the development of 5 target genes could total $\$ 60$ million plus royalties. Schering and Myriad will receive worldwide rights to resulting pharmaceutical and diagnostic products, respectively.

28

TDC will fund Fibrogen's recombinant collagen program, which will develop recombinant collagens and gelatins for use as therapeutic and biomaterial applications. The first phase of funding will be $\sim \$ 3.2$ million, but the total milestone-dependent grants and equity loans could amount to \$28 million.

11.66 A five-year agreement using AMRAD's libraries and high-throughput screening technology to test natural-product extracts to identify compounds suitable for use in the treatment of asthma. AMRAD will receive \$11.66 million from Rhône, plus milestone payments and any royalties.

1 Cubist's high-throughput screening expertise (and antibacterial and antifungal targets) will be combined with Novalon's Biomolecular Recognition System to develop screening technologies for genomic targets. As well as paying royalties on any resulting products, Cubist will both purchase a $\$ 1$ million equity stake in Novalon and make research payments.

0.65 A series of R\&D agreements to continue development of PharmaDerm products using PharmaDerm's dermal drug delivery systems, which could reduce the side effects of certain drugs. Helix will have worldwide manufacturing and marketing rights for the products, and will provide $\$ 650,000$ in development funding.

Using Biomira's vaccine development and manufacturing expertise and Chiron Therapeutics' biological-product marketing experience, the partnership will codevlop Biomira's immunotherapeutic synthetic vaccine, Theratope, which stimulates a patient's immune system. The companies will share clinical, regulatory, and research costs, but Chiron will make an upfront payment as well as milestone payments to Biomira, and Chiron will market and distribute the vaccine-aimed at metastatic breastcancer treatment-in Europe and the United States.

British Biotech will provide funding for a three-year research agreement to develop drugs for the treatment of tissue-destroying diseases, using SynPhar's design and small-molecule synthesis knowledge. British Biotech will receive worldwide development and marketing rights to any resulting products. 